\title{
Kajian Fisik Pesisir Kulon Progo untuk Penentuan Zona Kawasan Mangrove dan Tambak Udang
}

\section{Riski Tanjung ${ }^{1}$, Nurul Khakhim ${ }^{1}$, dan Rustadi ${ }^{2}$}

\author{
${ }^{1}$ Fakultas Geografi, Universitas Gadjah Mada, Yogyakarta, Indonesia \\ ${ }^{2}$ Fakultas Pertanian, Universitas Gadjah Mada, Yogyakarta, Indonesia \\ Email koresponden: riskitanjung@gmail.com
}

Diterima : Juli 2017 ; Direvisi : Agustus 2017; Dipubikasikan: September 2017

๔ 2017 Fakultas Geografi UGM dan Ikatan Geograf Indonesia.

\begin{abstract}
Abstrak Pesisir Kulon Progo saat ini memiliki habitat mangrove dan lahan tambak udang. Perkembangan salah satunya, akan mengakibatkan berkurangnya luas lahan yang lain. Penelitian ini bertujuan untuk (1) menganalisis kondisi fisik wilayah pesisir Kulon Progo, (2) menentukan zona yang sesuai untuk kawasan mangrove dan/atau tambak udang di wilayah pesisir Kulon Progo, dan (3) menyusun rekomendasi pengelolaan kawasan mangrove dan atau tambak udang di wilayah pesisir Kulon Progo. Pengambilan sampel dilakukan dengan purposive sampling. Data kondisi fisik lahan diperoleh melalui observasi dan pengukuran di lapangan. Zonasi kawasan mangrove dan tambak udang dilakukan dengan reinterpretasi peta dan metode matching dengan parameter kesesuaian yang telah ditentukan sebelumnya. Strategi pengelolaan kawasan mangrove dan tambak udang dilakukan dengan menganalisis faktor internal dan eksternal wilayah menggunakan analisis SWOT. Hasil penelitian menunjukkan bahwa kondisi fisik wilayah pesisir Kulon Progo terdiri atas substrat dasar berbatu, lempung bergeluh, lempung, lempung berpasir, berpasir. Pasang surut air laut berkisar 1-1,1 m, salinitas air antara 0-29\%o, kecerahan air antara $0 \mathrm{~cm}$ - tidak terukur, dan suhu air antara $27-34,1^{\circ} \mathrm{C}$. Kondisi fisik pesisir Kulon Progo ada yang sesuai (S2) untuk pertumbuhan mangrove dan tambak udang, serta ada yang tidak sesuai untuk keduanya. Zona yang sesuai (S2) untuk kawasan mangrove terdapat di muara Sungai Bogowonto seluas 1,58ha. Zona yang sesuai (S2) untuk kawasan tambak udang seluas 134,49ha. Strategi pengelolaan kawasan untuk zonasi mangrove di lokasi kajian yang dapat direkomendasikan dalam penelitian ini antara lain (1) pelestarian dan pengembangan kawasan mangrove dalam bentuk kawasan konservasi sekaligus sebagai objek wisata dan pendidikan, (2) mengembangkan dan meningkatkan komitmen masyarakat atas arti penting kawasan mangrove untuk menghambat alih fungsi kawasan mangrove, (3) mengembangkan zona mangrove dengan menanam jenis mangrove yang sesuai dengan kondisi fisik lahan, (4) melakukan tindakan persuasif dalam mewujudkan konsensus masyarakat untuk membentuk kawasan lindung mangrove.
\end{abstract}

Kata kunci: kondisi fisik, zonasi, mangrove, tambak udang, wilayah pesisir Kulon Progo

\begin{abstract}
The Coast of Kulon Progo is currently the habitats for mangroves and shrimp ponds, i.e., where the development of the former reduces the latter. This research aimed to (1) analyze the physical condition of the coast, (2) determine the suitable zone for mangrove areas and/or shrimp ponds along the coast, and (3) propose a recommendation for mangrove and/or shrimp pond management along the coast. The samples were selected using purposive sampling technique. The research also employed field observation and measurement to acquire the physical condition of the land. The zonation of mangrove area and shrimp pond was obtained from map reinterpretation and matching technique with the predefined parameters of land suitability. As for the mangrove and shrimp pond management strategies, the research used SWOT analysis to study both of the internal and external factors in the study area. The results showed that the substrate of the coast was composed of rock, clay loam, clay, sandy clay, and sand. Aside from the substrate, the physical condition of the coast was characterized by sea tide (1-1.1 m), salinity (0-29\%), water transparency (0 $\mathrm{cm}$-undetectable), and temperature $\left(27-34.1^{\circ} \mathrm{C}\right)$. These characteristics classified the coast into two types of suitability for mangrove growth and shrimp pond development, namely suitable (S2) and unsuitable. While the suitable (S2) zone for mangrove development occupied 1.58 ha area in the mouth of Bogowonto River, the suitable (S2) zone for shrimp pond was considerably larger, i.e., 134.49 ha. The recommended strategies for mangrove zone management in the study area are as follows: (1) mangrove preservation and development as a conservation area and an object for tourist destination and education, (2) the encouragement and improvement of community's commitment to accentuating the essential functions of mangrove areas and to decelerating any land use conversions of mangrove zone, (3) the development of mangrove zone by planting suitable mangrove species with the physical condition of the area, and (4) the implementation of persuasive actions in actualizing community consensus on mangrove area development.
\end{abstract}

Keywords: Physical Condition, Zonation, Mangrove, Shrimp Pond, Coast of Kulon Progo

\section{PENDAHULUAN}

Pesisir Kulon Progo berbatasan langsung dengan Samudra Hindia dan merupakan muara 3 sungai yaitu Sungai Progo, Sungai Serang, dan Sungai Bogowonto.
Djohan (2000) menyebutkan potensi tumbuh mangrove di muara sungai dapat mencapai 95\%, sehingga pesisir Kulon Progo diperkirakan memiliki potensi yang tinggi untuk pertumbuhan dan pengembangan hutan 
mangrove. Hutan mangrove merupakan ekosistem yang sangat penting bagi kelangsungan ekosistem wilayah pesisir dan laut (Hudaya dkk., 2014; Imburi dkk., 2015; Nurrohmah dkk., 2016). Selain itu, udang banyak dibudidayakan Kulon Progo karena kondisi lahan yang memungkinkandan sangatmenguntungkan.Sayangnya, perkembangan kedua potensi tersebut seringkali bertolak belakang (Hidayatullah, 2013; Faturohmah dan Marjuki, 2017). Perluasan salah satunya akan menyebabkan berkurangnya luas lahan untuk yang lain. Oleh karenanya, kajian fisik diperlukan sebagai dasar pemetaan wilayah untuk berbagai pemanfaatan yang optimal.

Peraturan Daerah (Perda) Daerah Istimewa Yogyakarta (DIY) No. 16 tahun 2011 menyatakan bahwa zona perikanan budidaya berada di kawasan yang sama dengan liputan mangrove eksisting di Kulon Progo, sedangkan zona mangrove belum ditentukan secara jelas. Perda DIY No.1 tahun 2012 juga belum secara jelas menyebutkan zona mangrove, sedangkan kawasan budidaya air payau berada di Kecamatan Temon, Wates, dan Galur. Mangrove yang berada di Daerah Istimewa Yogyakarta yang ada saat ini tumbuh secara alami hanya di Kulon Progo, sehingga diperlukan kajian fisik wilayah Pesisir Kulon Progo untuk penentuan zona mangrove dan tambak udang. Tujuan penelitian ini adalah untuk (1) menganalisis kondisi fisik wilayah; (2) menentukan zona yang sesuai untuk kawasan mangrove dan/atau tambak udang; dan (3) menyusun rekomendasi pengelolaan kawasan mangrove dan atau tambak udang di pesisir Kulon Progo.

\section{METODE PENELITIAN}

Penelitian berlokasi di pesisir Kabupaten Kulon Progo, Daerah Istimewa Yogyakarta. Data primer yang dibutuhkan dalam penelitian ini meliputi suhu air, salinitas, substrat dasar, kecerahan air, jenis plankton, dan jenis vegetasi. Data sekunder dalam penelitian ini meliputi peta bentuklahan skala 1:50.000, peta jenis tanah skala 1:50.000, peta Rupa Bumi Indonesia (RBI) skala 1:25.000, data pasang surut tahun 2011 dan 2012, Rencana Tata Ruang Wilayah (RTRW) Kabupaten Kulon Progo, RTRW DIY, Undang-undang (UU) No. 27 Tahun 2007, dan UU No. 1 Tahun 2014. Data kondisi fisik diperoleh melalui observasi dan pengukuran di lapangan secara purposive sampling. Zonasi mangrove dan tambak udang dilakukan dengan reinterpretasi peta dan matching hasil pengukuran fisik di lapangan dengan parameter kesesuaian untuk mangrove dan/ atau tambak udang yang telah ditentukan sebelumnya. Strategi pengelolaan kawasan dilakukan menggunakan analisis SWOT. Metode matching untuk analisis zonasi menggunakan matriks kesesuaian lahan ditunjukkan pada Tabel 1 dan Tabel 2, sedangkan diagram alir penelitian disajikan dalam Gambar 1.

Tabel 1. Matriks Kesesuaian Lahan untuk Mangrove

\begin{tabular}{lllll}
\hline No & Parameter & S1 & S2 & N \\
\hline 1 & Salinitas $(\%)$ & $1,0-2,5$ & $0,5-<1,0$ atau $>2,5-3,0$ & $<0,5$ atau $>3,0$ \\
2 & Substrat dasar & berlumpur & berpasir & berbatu \\
3 & Pasang surut $(\mathrm{m})$ & $1,5-2,0$ & $0,5-1,5$ atau $2,0-2,5$ & $<0,5$ atau $>2,5$ \\
\hline
\end{tabular}

Sumber : MacNae (1968); Giesen et al. (2007); Kusmana dkk. (2003)

Tabel 2. Matriks Kesesuaian Lahan untuk Tambak Udang

\begin{tabular}{lllll}
\hline No & Parameter & S1 & S2 & N \\
\hline 1 & Kelerengan $(\%)$ & $0-1$ & $1-2$ & $>2$ \\
& & $\begin{array}{l}\text { Lempung, } \\
\text { lempung } \\
\text { berpasir }\end{array}$ & $\begin{array}{l}\text { Geluh, geluh berlempung, geluh } \\
\text { berpasir, geluh lempung berdebu }\end{array}$ & Pasir \\
& Substrat dasar & $80-100$ & $60-<80$ & $<60$ \\
3 & Kecerahan $(\%)$ & $2,9-3,0$ & $2,5-<2,9$ atau $>3,1-3,3$ & $<2,5$ atau $>3,3$ \\
4 & Salinitas $(\%)$ & $28-30$ & $26-<28$ atau $>30-32$ & $<26$ atau $<32$ \\
5 & Suhu $\left({ }^{\circ} \mathrm{C}\right)$ & $1-3$ & 0,5 atau $>3-3,5$ & $<0,5$ atau $>3,5$ \\
\hline
\end{tabular}

Sumber: Effendi (2003); FAO (1994) 


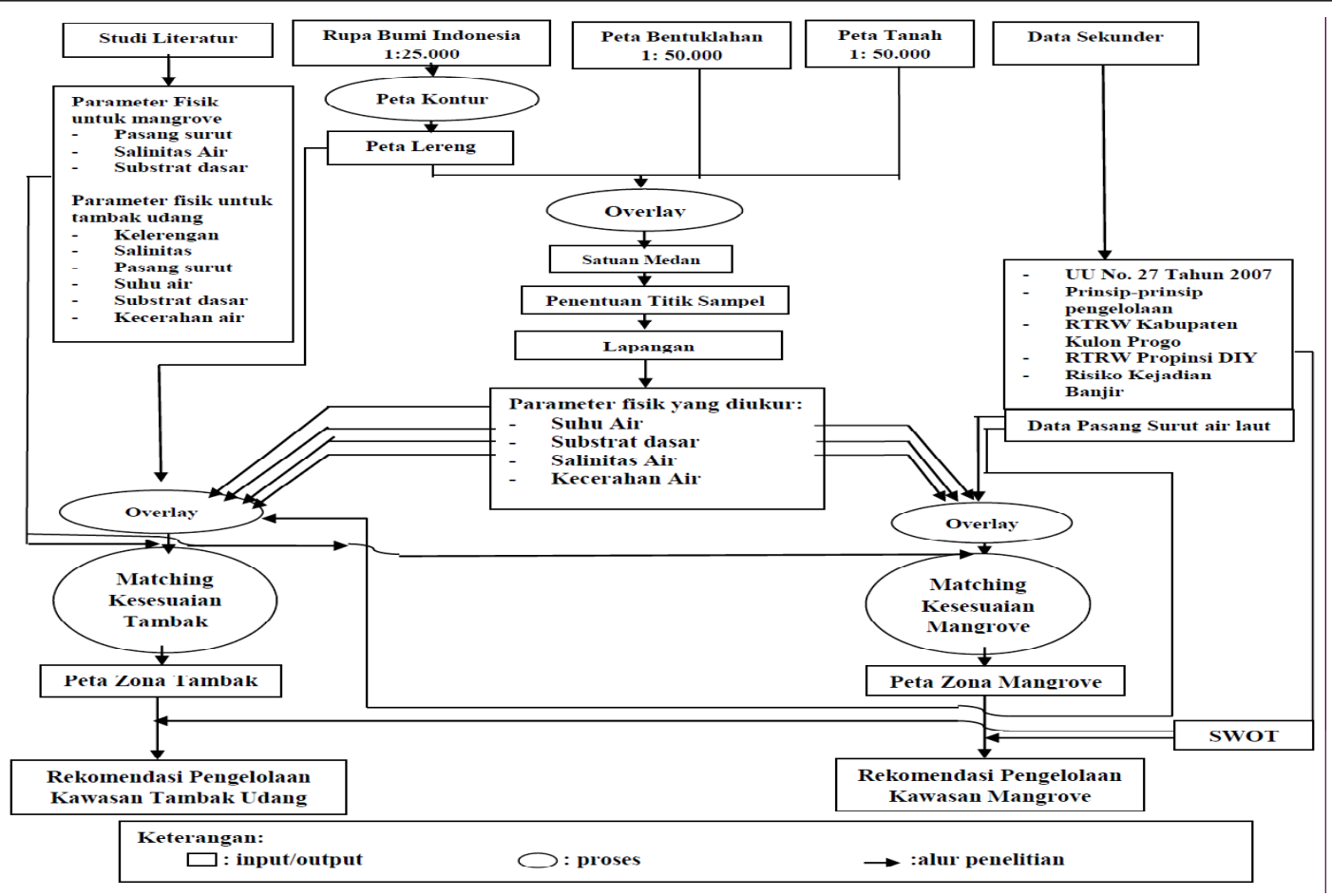

Gambar 1. Diagram Alir Penelitian

\section{Deskripsi Wilayah Penelitian \\ Luas, Letak, dan Batas Wilayah}

Wilayah penelitian terletak antara $110^{\circ} 1^{\prime} 37^{\prime \prime}$ $110^{\circ} 16^{\prime} 26^{\prime}$ Bujur Timur dan 7³8’42” - 759'3” Lintang Selatan. Kabupaten Kulon Progo memiliki panjang garis pantai $\pm 25 \mathrm{~km}$. Kecamatan yang memiliki wilayah pesisir meliputi Kecamatan Temon, Wates, Panjatan, dan Galur. Batas wilayah penelitian di sebelah barat adalah Kabupaten Purworejo, sedangkan batas di sebelah timur adalah Kabupaten Bantul. Batas bagian utara adalah bentuklahan Perbukitan Kulon Progo, sedangkan bagian selatan dibatasi garis pantai yang berbatasan langsung dengan Samudra Hindia.

\section{Topografi}

Topografi wilayah penelitian berupa dataran yang landai. Arksonkae (1993) menyatakan bahwa topografi sebagai salah satu faktor penting yang mempengaruhi karakteristik struktur mangrove, terutama komposisi, jenis, distribusi jenis dan ukuran. Topografi ideal untuk mangrove adalah topografi yang landai sampai dengan datar karena keterdapatan mangrove berkaitan dengan pasang surut dan sedimentasi. Kordi (2012) berpendapat bahwa wilayah dengan topografi landai adalah ideal untuk tambak karena biaya pembangunan tambak lebih murah.

\section{Hidrologi}

Menurut Widiyanto (1986) permasalahan drainase di wilayah penelitian disebabkan daerah yang sangat datar, sedangkan air dari daerah pegunungan relatif besar. Saat musim penghujan, daerah sekitar Sungai Progo dan Sungai Serang banjir, sedangkan daerah sekitar muara Sungai Bogowonto sering terbendung di musim kemarau. Apabila musim kemarau dan tidak ada hujan, muara Sungai Bogowonto akan tertutup dan akan tergenang dalam waktu lama dengan didominasi oleh air tawar. Namun demikian, pada musim penghujan muara akan terbuka dan kembali terjadi pasang surut. Perubahan sifat air pada musim kemarau dan penghujan berpengaruh pada kualitas air dan biota di daerah tersebut, termasuk mangrove dan udang.

\section{Oseanografi}

Menurut Sunarto (1994) tenaga laut yang mempengaruhi morfologi pantai ada 3, yaitu gelombang, arus laut dan pasang surut. Triatmojo (2008) menyatakan bahwa pada musim kemarau lokasi penelitian memiliki angin dominan kuat (20-25 m/ dt) dan konstan bertiup dari selatau atau tenggara, sedangkan pada musim penghujan angin lebih lemah $(<5 \mathrm{~m} / \mathrm{dt})$ dan lebih bervariasi dengan angin dominan dari barat daya sampai barat laut. Wilopo (2005) menyatakan bahwa arah angin dan aliran arus di Samudra Hindia berpengaruh terhadap sedimentasi dan penutupan muara Sungai Bogowonto yang terjadi pada bulan Agustus-November. Gelombang utama di pesisir Kulon Progo didominasi dari Selatan dan Tenggara. Kondisi pasang surut di wilayah penelitian merupakan tipe harian ganda. Data Pasang surut di lokasi kajian yang diperoleh dari dari Dinas Hidrooseanografi TNI AL Cilacap (DHO, 2011; 2012) tersaji pada Tabel 3. Tabel 3 juga menunjukkan data 
pengamatan yang menunjukkan bahwa wilayah kajian memiliki nilai pasang surut air laut rerata bulanan setinggi 1,1 m dengan rentang ketinggian antara $0,1 \mathrm{~m}$ sampai dengan 2,2 $\mathrm{m}$. Kondisi pasang tertinggi terjadi pada bulan purnama, sedangkan surut terendah terjadi pada kuarter 2 .

Tabel 3. Pasang Surut Air Laut Samudra Hindia Stasiun Pengamatan Pelabuhan Cilacap pada Tahun 2011 dan 20012

\begin{tabular}{lcccccccccccc}
\hline $\begin{array}{l}\text { Pasang surut air } \\
\text { laut }(\mathrm{m})\end{array}$ & Jan & Feb & Mar & Apr & Mei & Jun & Jul & Agu & Sep & Okt & Nov & Des \\
\cline { 2 - 10 } Tahun 2011 & & & & & & & & & & & & \\
Maksimum & 2,0 & 2,0 & 2,1 & 2,2 & 2,2 & 2,1 & 2,0 & 2,0 & 2,2 & 2,1 & 2,2 & 2,1 \\
Rerata & 1,1 & 1,1 & 1,1 & 1,1 & 1,1 & 1,1 & 1,1 & 1,1 & 1,1 & 1,1 & 1,1 & 1,1 \\
Minimum & 0,2 & 0,2 & 0,2 & 0,1 & 0,1 & 0,1 & 0,2 & 0,2 & 0,1 & 0,1 & 0,1 & 0,1 \\
Tahun 2012 & & & & & & & & & & & & \\
Maksimum & 2,0 & 2,0 & 2,1 & 2,2 & 2,2 & 2,1 & 2,1 & 2,0 & 2,1 & 2,2 & 2,2 & 2,1 \\
Rerata & 1,1 & 1,1 & 1,1 & 1,1 & 1,1 & 1,1 & 1,1 & 1,1 & 1,1 & 1,1 & 1,1 & 1,1 \\
Minimum & 0,2 & 0,2 & 0,2 & 0,1 & 0,1 & 0,1 & 0,1 & 0,2 & 0,2 & 0,2 & 0,1 & 0,1 \\
\hline
\end{tabular}

Sumber: Dinas Hidro-Oseanografi TNI AL (DHO, 2011; 2012)

\section{Jenis Tanah}

Jenistanah diwilayah penelitian terdiriatas regosol, gleisol, aluvial, dan kambisol. Tabel 4 menunjukkan wilayah penelitian didominasi jenis tanah regosol yang terdiri dari banyak kenampakan batu serta kerikil yang mengalami pelapukan belum sempurna. Jenis tanah regosol terdistribusi seluas $63,92 \%$ di wilayah dataran fluvio-marin berjarak dari pantai antara 1,0 km - 1,5 $\mathrm{km}$. Jenis tanah aluvial menempati wilayah-wilayah yang difungsikan sebagai area budidaya tanaman seperti sawah, kebun dan juga palawija. Beberapa desa seperti Galur dan Panjatan merupakan wilayah desa yang didominasi oleh jenis tanah aluvial, sedangkan wilayah Temon didominasi tanah aluvial yang paling kecil. Jenis tanah kambisol tersebar di sepanjang tepian Sungai Progo, yang termasuk wilayah Desa Banaran.

Tabel 4. Distribusi Jenis Tanah di Wilayah Penelitian

\begin{tabular}{lll}
\hline Jenis Tanah & Luas (ha) & Persentase (\%) \\
\hline Regosol & 1297.16 & 63.92 \\
Gleisol & 635.48 & 31.32 \\
Aluvial dan kambisol & 96.65 & 4.76 \\
Total area & $2,029.29$ & 100.00 \\
\hline
\end{tabular}

Sumber : Analisis Peta (2014)

\section{Jenis Vegetasi}

Vegetasi di wilayah penelitian bervariasi, dari tumbuhan perintis sampai tumbuhan tingkat tinggi. Vegetasi pada bentuklahan gisik didominasi vegetasi lahan kering, ditandai dengan banyaknya tumbuhan jenis semak (widuri dan jarong), herba, rumput lari, pohon cemara udang dan pandan pantai. Selain vegetasi lahan kering, di Desa Bugel dan dataran aluvial Desa Banaran didominasi oleh tanaman pertanian seperti padi, tebu, cabai, jagung, sawi. Vegetasi lahan basah yang mendominasi di seluruh titik pengamatan hanya terdapat di dataran aluvial Dusun Pasirkadilangu yang didominasi vegetasi mangrove.

\section{Jenis Plankton}

Plankton merupakan indikator kesuburan perairan. Jenis plankton terbanyak ditemukan di Muara Bogowonto. Sungai Serang didominasi Synedra sp., laguna Serang didominasi Chloroccocus sp. dan Cyclotela sp., muara Sungai Serang didominasi Tabellaria sp.. Kondisi sedikit berbeda ditemukan di muara Sungai Progo yang didominasi Closterium sp. dan Nitzchia sp., Sungai Progo didominasi Synechocytis sp. Kondisi yang berbeda juga ditemukan di Sungai Bogowonto yang didominasi Synedra sp. dan Nitzchia sp., muara Bogowonto didominasi Chloroccocus sp. dan Cyclotela sp., sedangkan sumur renteng warga tidak ditemukan plankton. 


\section{Penggunaan Lahan}

Penggunaan lahan pada bentuklahan gisik meliputi wisata pantai dan daerah lindung sempadan pantai. Barat Sungai Bogowonto banyak digunakan untuk tambak. Bentuklahan tanggul alam dan sebagian dataran aluvial dimanfaatkan untuk tegalan dan perkampungan. Penggunaan lahan di dataran aluvial dan swale sebagian besar untuk pertanian sayuran (terong, tomat, cabai, kubis, bayam, kentang, dan sawi) dan buah-buahan (semangka dan melon). Daerah swale banyak ditemukan sumur renteng untuk irigasi pertanian. Dataran banjir di barat muara Sungai Bogowonto banyak digunakan untuk sawah, kebun sayur dan habitat mangrove. Wilayah gumuk pasir sebagian besar berupa lahan kosong, sebagian kecil untuk pertanian, penanaman rumput, tanaman merambat, dan tempat menjemur enceng gondok.

\section{Kondisi Sosial}

Kondisi sosial yang dikaji dalam penelitian ini meliputi jumlah, pendidikan dan kesehatan, dan pekerjaan penduduk. Berdasarkan sensus tahun 2010 jumlah dan kepadatan penduduk tertinggi berada di Kecamatan Wates yang merupakan ibukota Kabupaten Kulon Progo. Jumlah dan kepadatan penduduk terendah adalah Kecamatan Temon. Rata-rata pemuda hanya bersekolah hingga tingkat SMA. Tingkat kesehatan penduduk masih kurang, beberapa desa belum memiliki puskesmas atau polindes. Tenaga kesehatan terdiri atas paramedis, dukun bayi, dan tukang pijat. Mata pencaharian penduduk meliputi pegawai negeri sipil, aparat desa, nelayan, buruh, petani, wiraswasta, tentara dan ibu rumah tangga. Sawitri (2012) menyatakan bahwa mayoritas penduduk di sekitar muara Bogowonto adalah petani, termasuk petani mangrove. Dusun Pasirmendit dan Pasirkadilangu banyak petani yang merangkap pekerjaan sebagai nelayan, sedangkan Desa Karangwuni sebagian besar penduduknya adalah nelayan.

\section{HASIL DAN PEMBAHASAN}

\section{Kondisi Fisik untuk Kawasan Mangrove}

Tumbuhan mangrove secara umum dapat berkembang pada kondisi lingkungan yang kurang baik, tetapi setiap tumbuhan mangrove memiliki kemampuan yang berbeda untuk mempertahankan diri atau beradaptasi terhadap kondisi fisik dan kimia lingkungannya. Parameter fisik yang penting bagi kehidupan mangrove, antara lain substrat dasar, pasang surut air laut, dan salinitas air. Parameter tersebut akan menjadi faktor pembatas bagi persebaran mangrove.

Substrat dasar yang didominasi substrat berpasir terdistribusi pada bentuklahan gisik muda, sebagian besar gisik dewasa, gisik tua, sebagian besar dataran fluvio-marin, dan gosong sungai. Substrat dasar berlempung terdistribusi pada dataran alluvial, tepi Sungai Bogowonto dan sekitar muara Bogowonto. Substrat dasar berbatu terdistribusi di tepi Sungai Progo. Luas daerah berpasir adalah 5.138,6 ha, luas wilayah berlempung 837 ha, dan luas wilayah berbatu 39,87 ha. Luas daerah yang terkena pasang surut adalah 5.632ha, sedangkan daerah yang tidak terkena pasang surut adalah 383 ha.

Wilayah penelitian didominasi salinitas $<0,5$ sampai dengan $>3,0$ ppt dengan luas wilayah 5.887,31 ha; luas wilayah dengan salinitas 0,5 ppt sampai dengan $<1,0$ ppt dan 2,5 ppt sampai dengan 3,0 ppt adalah 126,59 ha yaitu di muara Sungai Bogowonto, Laguna Serang, dan gosong Sungai Progo, sedangkan luas wilayah dengan salinitas 1,0 ppt sampai dengan 2,5 ppt adalah 1,58 ha yaitu wilayah yang terletak di bagian barat muara Bogowonto. Menurut hasil penelitian Giesen et.al. (2007) dan Supriharyono (2007), jenis mangrove yang dapat tumbuh baik di lokasi penelitian adalah Sonneratia caseolaris (untuk salinitas $<0,1 \mathrm{ppt}$ ), Avicennia marina dan Rhizopora mucronata (untuk salinitas 1,0-2,5 ppt). Berdasar salinitas air, wilayah penelitian yang sesuai untuk pertumbuhan mangrove adalah laguna dan muara Sungai Bogowonto.

\section{Kondisi Fisik untuk Kawasan Tambak Udang}

Tambak udang sebaiknya dibangun pada kondisi fisik yang ideal. Parameter kondisi fisik yang penting untukpembangunan tambakudangmeliputikelerengan, tekstur tanah, pasang surut, salinitas air, suhu air, dan kecerahan air. Menurut Zuidam (1983) kelerengan 0-2\% termasuk kelas lereng datar. Lereng datar inilah yang cocok untuk pengembangan tambak udang. Luas wilayah yang memiliki kelerengan 0 - 1\% adalah 5.600 ha, sedangkan luas wilayah yang memiliki kelerengan 1 - 2\% adalah 415,2 ha. Menurut Kordi (2012), tambak sebaiknya tidak memilih wilayah dengan kelerengan curam dan bergelombang karena memerlukan banyak biaya. Penggalian tanah yang terlalu dalam akan menyebabkan lapisan tanah permukaan yang subur terbuang, sehingga diperlukan pemupukan dosis tinggi dan dalam waktu yang relatif lama.

Perbedaan jenis substrat dipengaruhi oleh material yang dibawa dari hulu sungai. Djohan (2000; 2007) melaporkan perbedaan substrat dikarenakan Sungai Progo berhulu di Gunungapi Merapi yang membawa material pasir, sedangkan Sungai Bogowonto berhulu di Gunung Sindoro dan Gunung Sumbing yang membawa material lempung. Luas wilayah bersubstrat dasar berupa lempung, lempung berpasir adalah 538 ha; luas wilayah bersubstrat dasar berupa geluh, geluh berlempung, geluh berpasir, geluh lempung berdebu adalah 3.877,86 ha; dan luas wilayah bersubstrat dasar berupa pasir adalah 1.599,19 ha. Menurut Koordi (2012) substrat dasar untuk tambak harus kedap air (tidak porous), sehingga area dengan substrat dasar berupa 
lempung berpasir, lempung, dan geluh, geluh lempung berdebu sesuai untuk tambak. Area bersubstrat dasar lempung dan lempung berpasir merupakan area paling sesuai untuk membangun tambak karena subur, kedap air, dan sangat baik dibuat pematang. Berdasarkan substrat dasarnya, area yang sangat sesuai (S1) untuk membangun tambak udang adalah sebagian fluviomarin dan sebagian dataran aluvial, sedangkan wilayah yang tidak sesuai $(\mathrm{N})$ untuk membangun tambak udang adalah pada wilayah gisik muda.

Dinas Hidro-oseanografi (2011, 2012) menunjukkan bahwa pasang-surut di daerah penelitian adalah 0,1 - 2,2 $\mathrm{m}$, nilai rata-rata bulanan 1,1 m. Luas wilayah yang terkena pasang surut adalah 383,49 ha. Pasang surut di wilayah penelitian dikategorikan semidiurnal. Menurut Kordi (2012) pasang surut air laut yang memenuhi syarat untuk lokasi tambak adalah 1,5 - 2,5 m. Perbedaan pasang surut yang lebih rendah dari 1,5 m menyebabkan suplai air laut kurang mencukupi kebutuhan tambak. Menurut Poernomo (1992) pasang surut $0,1-2,2 \mathrm{~m}$ dikategorikan sangat rendah-cukup tinggi. Wilayah pesisir dengan air laut pasang maksimum 2-3 m dan rerata amplitudo 1,1 2,1 m termasuk layak bagi tambak udang di kawasan intertidal.

Sebagian besar wilayah penelitian memiliki kisaran salinitas $<2,5 \%$ o atau $>3,3 \%$. Wilayah yang memiliki kisaran nilai salinitas 2,5\%o - < 2,9\%o atau $>3,1 \%$ - 3,3\%o terdapat di laguna dan muara Bogowonto. Udang memiliki daya beradaptasi yang cukup besar terhadap salinitas, 3,0\%o - 4,5\%o (Tseng, 1987), tetapi pertumbuhan optimal udang adalah pada salinitas $1,5 \%$ - $2,5 \%$. Luas wilayah yang memiliki nilai salinitas $2,5 \%$ - $<2,9 \%$ atau $>3,1 \%$ - 3,3\%o adalah 39,05 ha, sedangkan luas wilayah yang memiliki nilai salinitas $<2,5 \%$ o atau $>3,3 \%$ o adalah $5.976,43$ ha. Wilayah penelitian secara alami memiliki salinitas yang sesuai (S2) untuk udang adalah muara Bogowonto.

Suhu air di wilayah penelitian adalah 270C 34,10C. Menurut Ahmad et.al. (1998) suhu air optimal untuk udang adalah 280C - 300C. Suhu <260C atau $>320 \mathrm{C}$ terdistribusi di sebagian besar wilayah penelitian, suhu 260C - <280C atau $>300 \mathrm{C}-320 \mathrm{C}$ terdistribusi pada bentuklahan gisik dan swale, suhu $280 \mathrm{C}$ - 300C terdistribusi pada bentuklahan gisik dewasa, swale, dataran fluvio-marin, dataran banjir, tanggul alam dan gosong sungai. Wilayah yang sesuai (S2) untuk tambak udang terdistribusi pada bentuklahan gisik, swale, dataran fluvio-marin, dataran banjir dan tanggul alam, serta gosong sungai. Suhu air dapat direkayasa dengan melakukan pergantian air, sehingga suhu air bukan faktor kunci dalam menentukan lokasi tambak udang.

Purnomo (1988) menyatakan terdapat korelasi antara kecerahan air dan warna air karena jenis dan kerapatan plankton. Perairan berwarna hijau muda memiliki nilai kecerahan $35 \mathrm{~cm}$, perairan berwarna hijau tua memiliki kecerahan $20 \mathrm{~cm}$, dan perairan berwarna coklat kehitaman serta mengandung bahan organik memiliki kecerahan $60 \mathrm{~cm}-80 \mathrm{~cm}$. Nilai kecerahan $80 \mathrm{~cm}-100 \mathrm{~cm}$ terdistribusi di laguna Serang dan muara Progo, nilai kecerahan $60 \mathrm{~cm}-80$ $\mathrm{cm}$ terdistribusi pada bentuklahan gisik dan daerah muara Sungai Bogowonto, dan nilai kecerahan $<60 \mathrm{~cm}$ mendominasi wilayah penelitian. Luas wilayah dengan kecerahan $<60 \mathrm{~cm}$ adalah $5.465,84$ ha, luas wilayah dengan nilai kecerahan $60 \mathrm{~cm}-80 \mathrm{~cm}$ adalah 532,68 ha, sedangkan luas wilayah dengan nilai kecerahan $80 \mathrm{~cm}$ - $100 \mathrm{~cm}$ adalah 16,95ha. Sellers and Morkland (1987) menyatakan bahwa kecerahan perairan $<3 \mathrm{~m}$ adalah tipe perairan eutropik, antara $3 \mathrm{~m}-6 \mathrm{~m}$ adalah tipe perairan mesotropik, dan $>6 \mathrm{~m}$ adalah tipe perairan oligotropik. Wilayah penelitian ini termasuk kategori perairan eutropik.

\section{Zonasi Kawasan Mangrove}

Penentuan zona mangrove menggunakan parameter fisik yang terdiri atas substrat dasar, pasang surut air laut, dan salinitas. Zonasi kawasan mangrove dibedakan menjadi 3 kelas, yaitu wilayah yang sangat sesuai (S1), sesuai (S2), dan tidak sesuai (N). Berdasarkan Gambar 2, area S2 untuk mangrove adalah seluas 1,58 ha dengan distribusi di sekitar muara Bogowonto. Wilayah ini terkena pasang surut air laut, memiliki substrat dasar berupa lempung, salinitas air yang rendah, dan jenis mangrove yang cocok adalah Avicennia spp. serta Sonneratia spp. Menurut Sawitri (2012) di wilayah tersebut secara alami tumbuh vegetasi dan tegakan mangrove yang didominasi spesies Sonneratia spp. Kesesuaian lahan pada tingkat tidak sesuai $(\mathrm{N})$ seluas $6.013,89$ ha berada di Kecamatan Panjatan, Galur, dan Wates.

\section{Zonasi Kawasan Tambak Udang}

Berdasarkan peta hasil analisis yang telah dibuat (Gambar 3), wilayah yang sesuai untuk tambak adalah bentuklahan gisik muda, gisik dewasa, dan laguna, dengan luas 383,49 ha (termasuk sempadan pantai seluas 249 ha). Substrat dasar berupa substrat berbatu, berpasir, lempung, lempung berpasir, dan lempung bergeluh. Substrat dasar berbatu dan berpasir tidak sesuai untuk pengembangan tambak udang, sehingga pada wilayah penelitian tidak ada yang sangat sesuai (S1). Salinitas yang relatif rendah dapat diatasi dengan mengambil air dari laut. Substrat dasar yang berpasir dapat diatasi dengan konstruksi plastik. Tambak plastik merupakan tambak yang dilapisi polyetilene, sehingga air tidak meresap ke tanah (Priyono, 2004; Triyatmo, 2010). Sistem budidaya udang semi intensif atau intensif yang mengandalkan pakan buatan di mana kecerahan/kesuburan perairan bukan lagi menjadi faktor pembatas. 


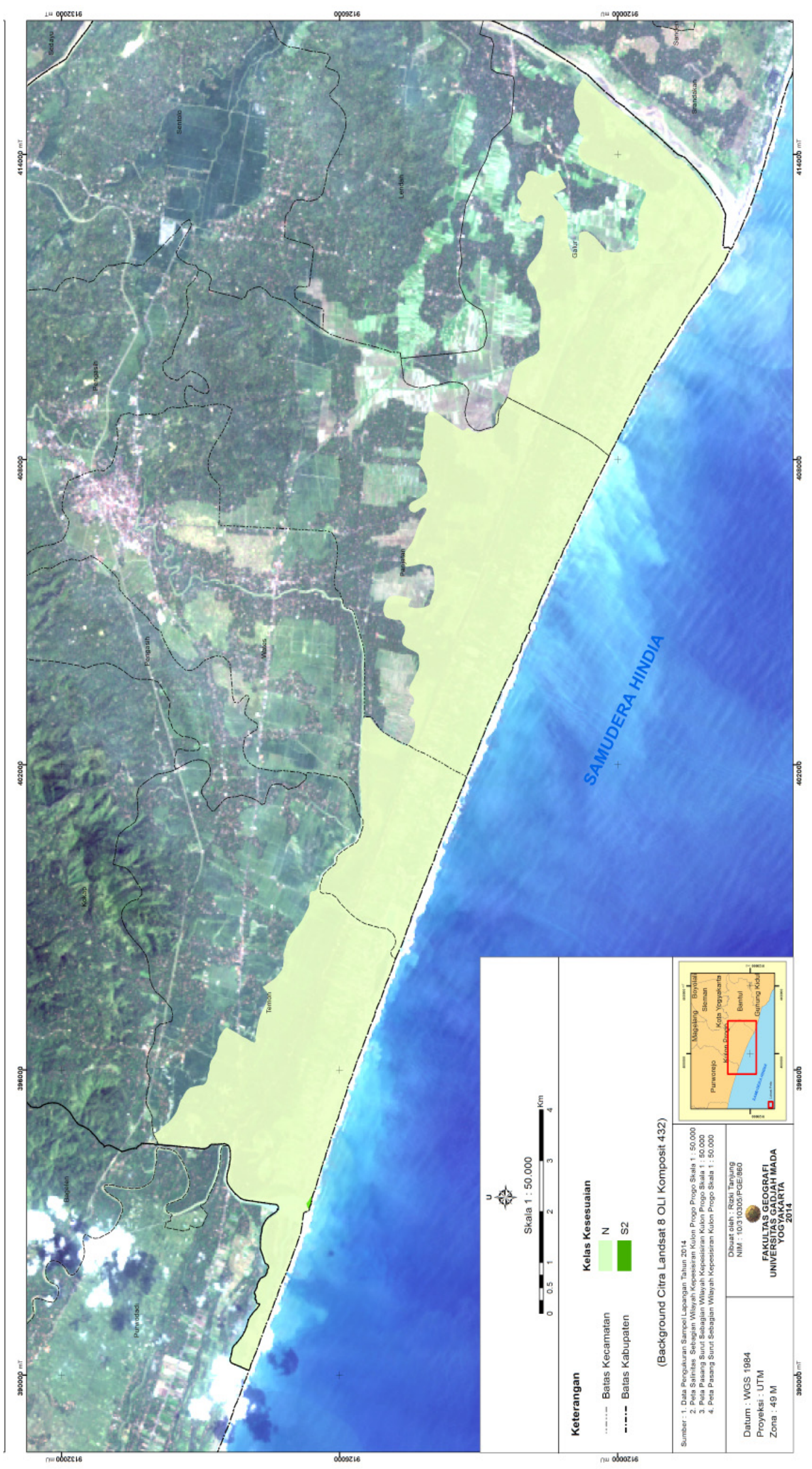

Gambar 2. Peta Kesesuaian Lahan untuk Kawasan Mangrove 


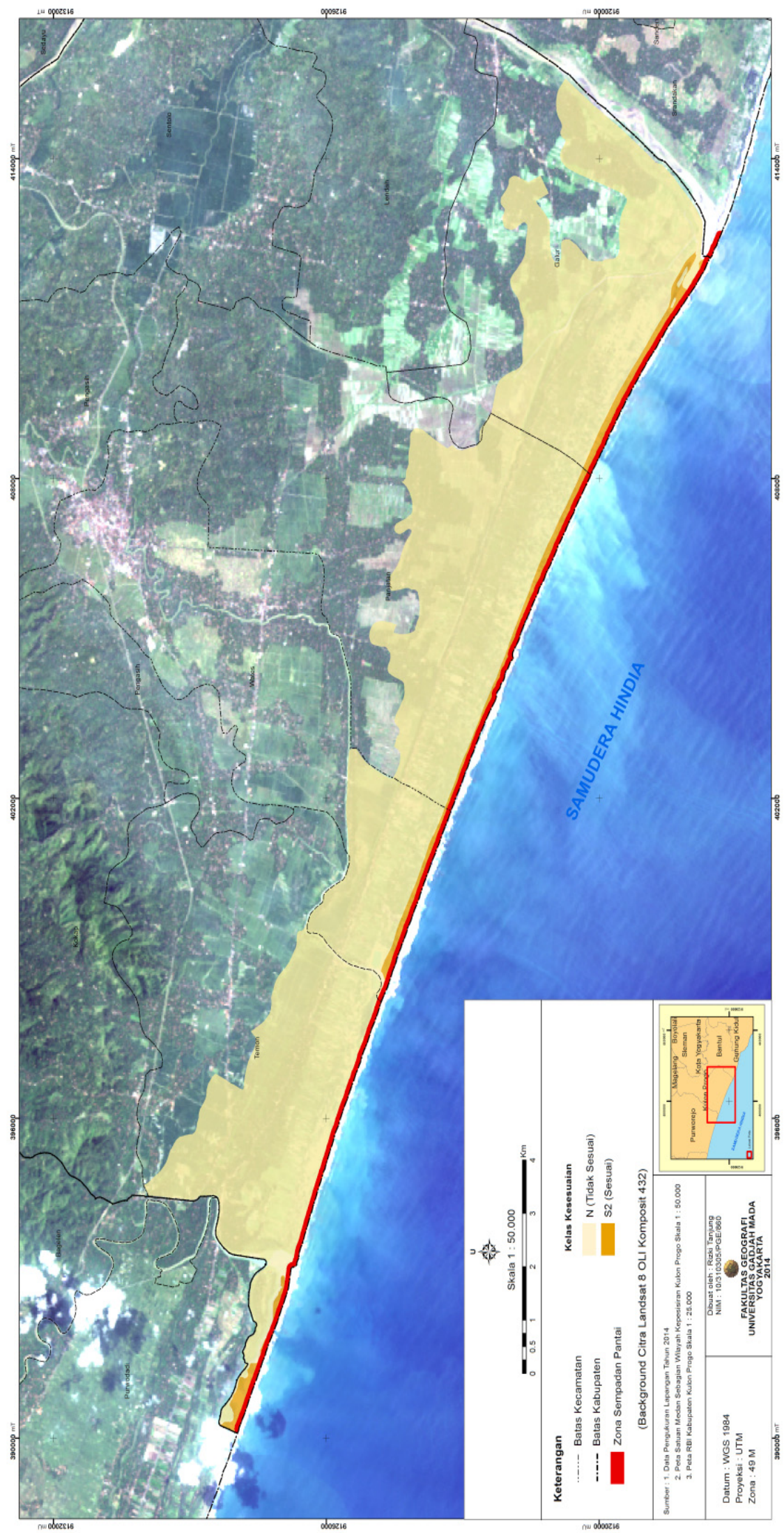

Gambar 3. Peta Kesesuaian Lahan untuk Kawasan Tambak Udang dan Zona Sempadan Pantai 


\section{KESIMPULAN}

Kesimpulan yang dapat ditarik dari penelitian yaitu terdapat sejumlah lahan yang sesuai (S2) dan yang tidak sesuai $(\mathrm{N})$, tetapi tidak terdapat lahan yang sangat sesuai (S1) untuk mangrove dan atau tambak udang; Zonasi mangrove dilakukan dalam bentuk kawasan konservasi, yakni zona inti berupa lahan mangrove di muara Sungai Bogowonto dan zona pemanfaatan di kawasan sempadan, sedangkan zonasi kawasan tambak udang tersebar di pesisir Kecamatan Temon, Wates, Panjatan, dan Galur; dan Strategi pengelolaan wilayah untuk zonasi mangove antara lain dapat dilakukan dengan (1) pelestarian dan pengembangan kawasan mangrove dalam bentuk kawasan konservasi untuk melestarikan keragaman hayati, wisata dan pendidikan, (2) sosialisasi keberadaan dan manfaat mangrove terutama pada masyarakat Kulon Progo dan masyarakat sepanjang DAS Bogowonto, (3) menyebarluaskan keberadaan kawasan mangrove Bogowonto sebagai tujuan wisata dan pendidikan serta menanam jenis mangrove yang sesuai dengan kondisi fisik lahan, (4) melakukan tindakan-tindakan persuasif dalam mewujudkan konsensus untuk membentuk kawasan lindung mangrove.

\section{DAFTAR PUSTAKA}

Ahmad, T. (1998). Budidaya Bandeng Secara Intensif. Jakarta: PT. Penebar Swadaya.

Arksonkae, S. (1993). Ecology and Management of Mangroves. Bangkok, Thailand: IUCN.

Badan Pusat Statistik. (2012). Kabupaten Kulon Progo Dalam Angka 2012. Wates: BPS Kabupaten Kulon Progo.

BAPPEDA Kabupaten Kulon Progo. (1987). Potensi Perikanan Pantai Daerah Istimewa Yogyakarta Tahun 1986/1987. Laporan Penelitian. Yogyakarta: BAPPEDA Kabupaten Kulon Progo dan Departemen Pendidikan dan Kebudayaan serta Jurusan Perikanan Universitas Gadjah Mada.

Dinas Hidro-oseanografi. (2011). Daftar Pasang Surut Kepulauan Indonesia (Tides Table, Indonesian Archipelagos). Stasiun Pengamatan Pantai Cilacap Tahun 2011. Jakarta: Dinas Hidro-Oseanografi (DHO TNI AL).

Dinas Hidro-oseanografi. (2012). Daftar Pasang Surut Kepulauan Indonesia (Tides Table, Indonesian Archipelagos). Stasiun Pengamatan Pantai Cilacap Tahun 2012. Jakarta: Dinas Hidro-Oseanografi (DHO TNI AL).

Djohan, T.S. (2000). Prospek Pengembangan Mangrove di Pantai Selatan Yogyakarta. Makalah dalam Workshop Regional Mangrove : Rehabilitasi Hutan Mangrove Melalui Pemberdayaan Masyarakat Dalam Rangka Otonomi Daerah. Yogyakarta: Pusat Pengembangan Rehabilitasi Mangrove INSTIPER.
Djohan, T.S. (2007). Distribusi Hutan Bakau di Laguna Pantai Selatan Yogyakarta. Jurnal Manusia dan Lingkungan, 14(1), 15 - 25.

Effendi, H. (2003). Telaah Kualitas Air Bagi Pengelolaan Sumberdaya dan Lingkungan Perairan. Yogyakarta: Penerbit Kanisius.

FAO. (1994). Mangrove Forest Management Guidelines. Roma: United Nation.

Faturrohmah, S. \& Marjuki, B. (2017). Identifikasi Dinamika Spasial Sumberdaya Mangrive di Wilayah Pesisir Kabupaten Demak. Majalah Geografi Indonesia, 31(1), 56 - 64.

Giesen, W., Wulffraat, S., Zieren, M. \& Scholten, L. (2007). Mangrove Guidebook for Southeast Asia. Bangkok: Dharmasarn Co., Ltd.

Hidayatullah, T. (2013). Evaluasi Ekonomi Kawasan Tambak dan Mangrove Pasca Bencana Lumpur di Muara Sungai Porong Kabupaten Sidoarjo Jawa Timur. Majalah Geografi Indonesia, 28(2), 169 177.

Hudaya, Y.F., Hartono \& Murti, S.H. (2014). Pendugaan Potensi Cadangan Karbon Hutan di Atas Permukaan pada Ekosistem Mangrove Berbasis Synthetic Aperture Radar L-Band. Majalah Geografi Indonesia, 28(2), 188 - 199.

Imburi, C.S., Danoedoro, P., \& Murti, S.H. (2015). Pemetaan Hutan Mangrove di Estuari Sungai Andai, Menokwari Papua Barat Berdasarkan Metode Density Slicing Berbasis Citra ALOS AVNIR-2. Majalah Geografi Indonesia, 29(1), 19 -30 .

Koordi, G. (2012). Jurus Jitu Pengelolaan Tambak Untuk Budidaya Perikanan Ekonomis. Yogyakarta: Lily Publisher.

Kusmana, C., Wilarso, S., Hilwan, I., Pamoengkas, P., \& Wibowo C. (2003). Teknik Rehabilitasi Mangrove. Bogor: Fakultas Kehutanan, Institut Pertanian Bogor.

Macnae, N. 1968. A General Accountu of The Fauna and Flora of Mangrove Swamp and Forest in The Indo-West Pasific Region. Adu. Mar. Bio., 6, 73270.

Nurrohmah, E., Sunarto \& Khakhim, N. (2016). Pemilihan Lokasi Kawasan Konservasi Mangrove dengan Pendekatan SIG Partisipatif di Wilayah Pantai Kabupaten Demak. Majalah Geografi Indonesia, 30(2), 149 - 168.

Peraturan Daerah DIY No. 16 tahun (2011) tentang Rencana Zonasi Wilayah Pesisir dan Pulau-Pulau Kecil Provinsi Daerah Istimewa Yogyakarta tahun 2011-2030.

Priyono, S.B. (2004). Pemanfaatan Foto Udara dan Sistem Informasi Geografi untuk Perencanaan Pengembangan Tambak Biocrete (Kasus di Pantai 
Selatan Kabupaten Bantul). Tesis. Yogyakarta: Program Pasca Sarjana, Universitas Gadjah Mada.

Purnomo. (1992). Pemilihan Lokasi Tambak Udang Berwawasan Lingkungan. Seri Pengembangan Hasil Penelitian No. PHP/KAN/ PATEK/004/1992.

Sawitri, R. (2012). Strategi Pengelolaan Lingkungan pada Ekosistem Mangrove di Sekitar Muara sungai Bogowonto Kabupaten Kulon Progo. Tesis. Yogyakarta: Sekolah Pascasarjana, Program Studi Ilmu Lingkungan, Konsentrasi Magister Pengelolaan Lingkungan, Universitas Gadjah Mada.

Seller \& Markland, H.R. (1987). Decaying Lake The Origin and Control of Cultural Eutrophication Principles and Technique in the Environmental Sciences. New York: John Wiley and Sons. Ltd.

Sunarto. (1994). Pelestarian Morfologi Pantai Akibat Pertambakan di Muara Ngebum Kabupaten Kendal. Laporan Penelitian. Yogyakarta: Fakultas Geografi Universitas Gadjah Mada.

Supriharyono. (2000). Pelestarian dan Pengelolaan Sumberdaya Alam di Wilayah Pesisir Tropis. Jakarta: PT. Gramedia Pustaka Utama.

Triatmodjo, B. (2008). Teknik Pantai, Cetakan ke-5. Yogyakarta: Betta Offset.

Triyatmo. (2010). Management Practices of Shrimp Farming in Sandy Coastal Areas: A Case Study in Bantul, Indonesia. The International Seminar on Development of Coastal Sandy Area Towards Sustainable Agriculture. Yogyakarta-Indonesia, Februari 2010.

Tseng, W.Y., \& Ho, S.K. (1988). The Biology and Culture of Red Grouper. Koaksing: Chien Cheng Publisher.

Undang-undang No. 27 Tahun (2007) tentang Rencana Tata Ruang Wilayah Pesisir dan Pulau-Pulau Kecil.

Undang-undang No. 1 Tahun (2014) tentang Perubahan UU No. 27 Tahun 2007 Rencana Tata Ruang Wilayah Pesisir dan Pulau-Pulau Kecil.

Widiyanto. (1986). Geomorfologi Daerah GlagahBogowonto Propinsi Jawa Tengah-DIY. Laporan Penelitian. Yogyakarta: Fakultas Geografi, Universitas Gadjah Mada.

Wilopo, M.D. (2005). Karakter Fisik Oseanografi di Perairan Barat Sumatera dan Selatan JawaSumbawa Dari Satelit Multi Sensor. Bogor: Program Studi Ilmu Kelautan Fakultas Perikanan dan Ilmu Kelautan, Institut Pertanian Bogor.

Zuidam. R.A. (1983). Guide to Geomorfhology Ariel Photographic Interpretation and Mapping. Enschede, The Nederland: ITC. 